\title{
OBITUARY
}

\section{Sir Alexander Fleming}

Sir Alexander Fleming, Professor Emeritus of Bacteriology in the University of London and lately Principal of the Wright-Fleming Institute of Microbiology, died suddenly on March 11 at his home in London with a heart attack at the age of 73. He was buried in St. Paul's Cathedral on March 18.

Alexander Fleming, the son of a farmer, was born near Darvel, in Ayrshire, Scotland, on August 6, 1881, a notable year in the history of bacteriology. His father died when he was 7 years old, and at 13 years of age Alexander went to live with a doctor brother in London, where he continued his education for two or three years by attending the Polytechnic Institute in Regent Street. After four years as a clerk in the City, Fleming in 1902 became a student at St. Mary's Hospital Medical School, where he won the senior entrance scholarship in natural science and practically every class prize and scholarship during his student career. He qualified in 1906, and took his M.B., B.S. of London University in 1908 with honours in physiology, pharmacology, pathology, hygiene, and medicine and a University gold medal.

Immediately after qualification Fleming began his association with Almroth Wright in the Inoculation Department at St. Mary's Hospital, and continued to work in the same department for the rest of his life with the exception of an interlude during the first world war. He never ceased to pay tribute to the inspiring leadership of the man whom he regarded as the greatest of British bacteriologists. There is little doubt that in the early years he, like other assistants, and they were a distinguished team, was to a considerable extent the apprentice of Almroth Wright, whose dominant personality and fertile brain directed the general research programme of the Inoculation Department for many years. But even in the early days Fleming showed his ingenuity and originality in devising simple apparatus and techniques for tackling laboratory problems. His first publication in 1908 was a contribution to a symposium in the Practitioner on "The Opsonic Method of Vaccine Therapy." Fleming's article, running to 28 pages, was a critical analysis of the opsonic index which had recently been introduced by Almroth Wright as a laboratory indicator of the progress of patients with various infective diseases. Besides a detailed and critical examination of the various components in the opsonic index, Fleming made some interesting and original observations on auto-agglutination of red blood cells in infective conditions, which perhaps heralded the later discovery of the rapid sedimentation rate associated with infection. In the following year a brilliant essay on "Acute Bacterial Infections," which won him the Cheadle Gold Medal, was published in St. Mary's Hospital Gazette.

His technical skill was early exemplified by an article published in the Lancet in 1909 on a "Simple Method of Serum Diagnosis of Syphilis," some part of which is stiil used in the Institute. There were further publications on the opsonic index, on the use of salvarsan in the treatment of syphilis (it is noteworthy that Fleming was perhaps the first man to use the new chemotherapy in this country), and on the aetiology and vaccine treatment of acne vulgaris before the first world war directed his attention to wound infection and its control. In 1915 he published a most interesting article on the "Bacteriology of Septic Wounds," and a few years later he showed with Porteous that most wounds become infected with Streptococcus pyogenes after admission to hospital. These findings were confirmed and amplified in the second world war. As Wright's disciple he took an active part in the controversy on the physiological versus chemical treatment of wounds, and again his inventiveness in devising apparatus and experiments to test the validity of a hypothesis or statement was very well demonstrated. This work led on to one of his classical experiments, in which he showed that carbolic acid when added to blood in certain concentrations killed the leucocytes but not the patho- 
genic germs, so that the antiseptic actually helped rather than hindered bacterial multiplication.

In 1922 came the discovery of lysozyme. Following an observation that his own nasal secretion after a common cold had an inhibitory action on some of the bacteria present in the nose, he showed that this lytic substance was present in many tissues and secretions of the body and was also widely distributed in Nature. But, because it was not particularly active against pathogenic organisms in vitro, the medical world did not give it the attention it deserved. His work with lysozyme prepared the way for the epochmaking discovery of penicillin.

Fleming had been studying variation in the staphylococcus, which meant that he was frequently examining colonies of that organism as they appeared on ordinary nutrient agar. As a result of this exposure a mould appeared on the culture medium some days later, and Fleming noticed the unusual phenomenon of the disappearance of staphylococcal colonies around the mould. His first paper describing his work with the active principle of this mould, which he named penicillin, showed that he appreciated the great potentialities of this substance as a new kind of antiseptic, particularly as it had no toxic effect on the phagocytic leucocytes. A few years later he reported that "it has been used on a number of indolent septic wounds and has certainly appeared to be superior to dressings containing potent chemicals."

Following the introduction of penicillin as an antibiotic drug, Fleming devised a number of microtechniques for its estimation in serum, etc., which became widely used. He was among the first to use phase-contrast microscopy in this country, and with its help he showed that, contrary to a recent claim, flagella were closely associated with bacterial motility. $\mathrm{He}$ made innumerable interesting discoveries which have never been published, and just before he died he had been demonstrating to us the effect of different qualities of paper in bringing out the pigment of chromogenic bacteria.

Fleming was a reticent. taciturn, and humble man, with an independent mind, great tenacity of purpose. a tough yet sensitive personality, and abiding loyalty. He was a born naturalist, keenly observant of everything around him, and always ready to devise and test new methods for studying germs in the laboratory or seeds and plants in the garden. He accepted the many honours that were showered upon him modestly and unaffectedly. The simple kind of tribute touched him most, such as a collection of signatures or a letter from a child or from some poor person who had benefited from penicillin. He had been looking forward to working again with opsonin, phagocytes. and lysozyme, for the natural defences of the body $\rightarrow$ were his constant interest. Now, instead, we mourn the loss of a great scientist and a great man.

\section{ROBERT CRUICKSHANK.}

\section{Professor H. M. Turnbull}

We regret to announce the death on September of Professor H. M. Turnbull, Emeritus Professor Morbid Anatcmy in the University of London. was an honorary member of the Association Clinical Pathologists. It is hoped to include obituary notice in the next issue. 